\title{
Revenue Recognition Dilemma under International Financial Reporting Standard (IFRS 15): Perspectives from Key Impacted Firms in Nigeria
}

\author{
Olubunmi Adewole Ogunode ${ }^{1, *}$, Rafiu Oyesola Salawu ${ }^{2}$ \\ ${ }^{1}$ Department of Accounting, Faculty of Management Sciences, Babcock University, Nigeria \\ ${ }^{2}$ Department of Management and Accounting, Obafemi Awolowo University, Nigeria
}

Received June 14, 2021; Revised July 23, 2021; Accepted August 22, 2021

\section{Cite This Paper in the following Citation Styles}

(a): [1] Olubunmi Adewole Ogunode, Rafiu Oyesola Salawu, "Revenue Recognition Dilemma under International Financial Reporting Standard (IFRS 15): Perspectives from Key Impacted Firms in Nigeria," Universal Journal of Accounting and Finance, Vol. 9, No. 5, pp. 916 - 926, 2021. DOI: 10.13189/ujaf.2021.090503.

(b): Olubunmi Adewole Ogunode, Rafiu Oyesola Salawu (2021). Revenue Recognition Dilemma under International Financial Reporting Standard (IFRS 15): Perspectives from Key Impacted Firms in Nigeria.Universal Journal of Accounting and Finance, 9(5), 916 - 926. DOI: 10.13189/ujaf.2021.090503.

Copyright $\bigcirc 2021$ by authors, all rights reserved. Authors agree that this article remains permanently open access under the terms of the Creative Commons Attribution License 4.0 International License

\begin{abstract}
This study examined the post -implementation impact of IFRS 15 from the Nigerian perspective and challenges associated with the adoption. Four listed companies operating in IFRS 15 key impacted firms in Nigeria which accounts for $82 \%$ of total market capitalization as of April 2021 were selected. The data extracted were analyzed with the aid of tables, charts, ratios, percentages and content analysis. The study revealed that listed firms in Nigeria aligned with the need to adopt and fully implement IFRS 15 in their financial reporting in response to regulatory pressure and increased internationalization of their operations. The study, therefore, concluded that adoption and implementation of IFRS 15 had a positive effect on accounting numbers of listed firms in Nigeria. The study identified the proper identification and treatment of royalties, income taxes, proper delineation of revenues from contractual fees, the need for persistent contract modifications, capitalization of contract costs, and collectability issues, as key challenges of IFRS 15 implementation. The study recommended that the Board and Management of companies operating in the IFRS 15 impacted industries should always provide greater clarity on the basis used for arriving at the significant judgment calls they make. Also, the Financial Reporting Council and external auditors need to develop workable methodologies to monitor and tighten compliance with both quantitative and qualitative IFRS 15 disclosure
\end{abstract}

requirements.

Keywords IFRS 15, Revenue Recognition, Impacted Industries, Accounting Numbers, Market Capitalization

JEL Classification Code: M41

\section{Introduction}

The proper accounting treatment, measurement, and recognition of revenue have consistently engaged the attention of academic scholars, investors, market analysts, and financial enthusiasts over the years. This is due to the centrality of revenue in terms of corporate financial assessment, computation of income tax liabilities, and inter-firm comparisons [1,2]. In addition, the rapid globalization of the world economy which necessitates easy movement of private capital across financial borders demands that accounting numbers (of which revenue is a key component) should be reported in a way that is relevant, reliable, and comparable. Consequently, accounting standard-setting institutions such as the Financial Accounting Standards Board (FASB) and the International Accounting Standards Board (IASB) joined 
resources in May 2014 to develop the International Financial Reporting Standard focusing on revenues from contracts (IFRS 15) with implementation date set as 1 January 2018. The standard effectively replaces IAS 11 tagged "Construction contracts", IAS 18 tagged "Revenue" together with their associated interpretations due to observed shortcomings related to their complexities, disclosure gaps, and lack of uniformity in the application [3].

The fundamental elements of the standard reside in deciding what constitutes revenue and how and when it is to be so recognized in the books. Revenue, in this case, is said to occur when it can be proven that there is a transfer of goods or a provision of verifiable service by one party to another for a sum that corresponds to the consideration so expected as a contractual obligation. To prevent ambiguity and foster uniformity, the standard recommends a five-step model for revenue recognition: contract identification and definition, performance obligation identification, transaction price identification and allocation of same to corresponding performance obligations, revenue recognition timelines. This unique five-step model has been tagged as one of the most revolutionary innovations of IFRS [4].

IFRS is based on accrual accounting because it fosters transparency and facilitates comparability of entities based on similar yardsticks [5]. This comparability benefit is what has been touted as one of the panaceas for addressing the hydra-headed challenge posed by creative accounting and earnings management schemes [6]. However, a review of existing studies shows that notwithstanding the benefits of IFRS, there is an unsettled debate as to whether early IFRS adoption or later adoption (post-effective date of implementation) mitigates or encourages creative accounting opportunities [7,8,9]. Haggenuller [10] opined that this clarity is needed to ensure entities do not become susceptible to possible class-action lawsuits arising from defective revenue recognition measures. Furthermore, most available studies post-implementation have focused their reviews using models benchmarked on European business entities $[10,11,12]$ implying a dearth of reliable works projecting perspectives from emerging economies such as Nigeria. It is against this backdrop that this study is carried out to explore the revenue recognition dilemma from the perspectives of the industries most impacted by the adoption of IFRS 15 in Nigeria. The importance of the study is further underscored by the increasing internationalization of Nigerian business entities and the growing contribution of the Nigerian economy as one of the key emerging economies. Emphasis will therefore be placed on the post-implementation issues, challenges, and the impact of post-IFRS 15 adoptions in Nigeria.

The remainder of the paper is arranged as follows: Section 2 shows an examination of extant literature from the standpoint of conceptual development, theoretical framework, and empirical reviews. Sections 3 and 4 consider the methodology adopted, results, and discussion of the research findings while the conclusion and recommendations of the study are presented in section 5 .

\section{Literature Review}

\subsection{International Financial Reporting Standard (IFRS 15)}

The International Financial Reporting Standard (IFRS) is a set of universally accepted accounting standards governing the preparation and presentation of financial statements. IFRS 15 was introduced in May 2014, which concentrates on revenues earned from contracts with the exceptions of those related to leases, insurance, financial instruments, and certain monetary exchanges [12,13]. It also distinguishes between revenues and incomes while also highlighting operational definitions for some key fundamentals including contract modifications, multiple elements arrangements, variable or potential consideration, and the concept of transfer of control [14]. It is this concept of transfer of control (as opposed to transferring of risks and rewards) that sets it apart from previous revenue-focused standards $[15,4]$. Previous studies on the impact of IFRS adoption on corporate performance had yielded mixed results $[16,17]$. While some have observed a significant positive impact of IFRS adoption and implementation on quality of accounting numbers in terms of reliability, relevance, accuracy, and comparability of the reported numbers $[7,18]$ ), others have indicated either a nil or insignificant effect on reporting quality of accounting numbers $[19,20,21]$ as there are claims of reported increases in earnings smoothing and other associated creative accounting boobytraps. Nevertheless, there is a growing consensus that the adoption and implementation of updated or revised accounting standards such as IFRS 15 are capable of reducing information asymmetry and enhancing reporting quality [22] because of the unique recognition, measurement, presentation, and disclosure requirements of the standard [4].

\subsection{Revenue Recognition and Measurement}

Revenue is one of the most important metrics used to evaluate a firm's financial position, performance, viability, and prospects [23]. IFRS 15 simply defines it as "income arising in the course of an entity's ordinary activities" This simple definition in practical application is however difficult because of the increased resort to estimations and professional judgment [24,25]. The core recognition principles are three-fold: the first is to recognize revenue only when it can be proven that there is a transfer of goods or a provision of verifiable service by one party to another 
for a sum that corresponds to the consideration so expected as a contractual obligation. The second key principle is to decide the timing of the recognition either at a specific point in time or over an estimated period. The third principle is to decide the best adoption approach to be used by the entity i.e. whether the full retrospective or modified retrospective approach. To give effect to these principles, the standard recommends a five-step recognition model should be adopted as depicted in the figure 1 .

A thematic review undertaken by the Reporting Council of UK as of October 2019 showed that while sampled firms had improved on compliance with revenue recognition metrics, substantial gaps still existed in terms of fulfilling disclosure requirements especially in matters where significant judgment calls were made.

\subsection{Impacted Industries}

Impacted industries are the group of business entities whose financial reporting responsibilities are the most affected by the requirements of IFRS 15 . These entities relate to those involved in long-term projects, bundled contracts, licensing of intellectual properties, and customization of business products and services. The level of impact depends on the unique attributes of each qualifying contract, the nature of the industry, and the business models adopted by each reporting entity. Industries impacted include telecommunications, software, technology and healthcare [26,27], management consulting, construction and engineering [11], real estate $[28,29]$, manufacturing, automotive, transportation, and logistics [30], Utilities [31]. Other possible impacted industries include insurance and investment, foods and consumer goods, oil and gas [KPMG 32]. Beyond the impact on the accounting numbers of players in the identified industries, adoption of IFRS 15 is capable of forcing organizational changes to informational flows and applications set-up, increasing regulatory costs and capital market pressures on the organizations $[33,4]$. Due to the desire to minimize the severity of impact, the majority of first-time adopters utilized the modified retrospective approach to report their accounting numbers $[29,10]$.

\subsection{Empirical Review}

There have been a number of empirical studies on the subject of IFRS 15 especially as it relates to adoption, measurement, treatment and presentation issues. Some of these alongside their findings are briefly discussed hereunder.

Khamis [25] examined the IFRS 15 revenue recognition and measurement dilemma from the perspectives of the perceptions of preparers and users of accounting information in Egypt. The researcher utilized a combination of structured interviews, questionnaires, and case studies for data collection. The study found deficiencies in the level of preparedness of the proposed preparers thus increasing the risks of material misstatements occurring. This position was corroborated by the studies of Peters [53] which focused on respondents drawn from Belgium. This argument was further extended by Phang and Mahzan [54] who opined that only regulatory coercion stimulates improvement in the level of preparedness and hence the active implementation of IFRS 15 when a study of one hundred and fifty listed business entities in Malaysia was conducted.

Dalwai, Chugh, Dinesh and Mohammadi [34] evaluated the readiness of business entities based in Oman for the adoption of IFRS 15 in their financial reporting. Data was obtained through structured interviews of qualified accountants working at selected professional accounting firms. The study identified three key challenges as factors militating against the productive implementation of IFRS 15 in the country, which lack clarity on measurement metrics for non-cash consideration, definition challenges relating to proper identification of customers, and collectability challenges. Notwithstanding the challenges, the researchers opined that with improved training and enhanced internal control systems, implementation would be successful.

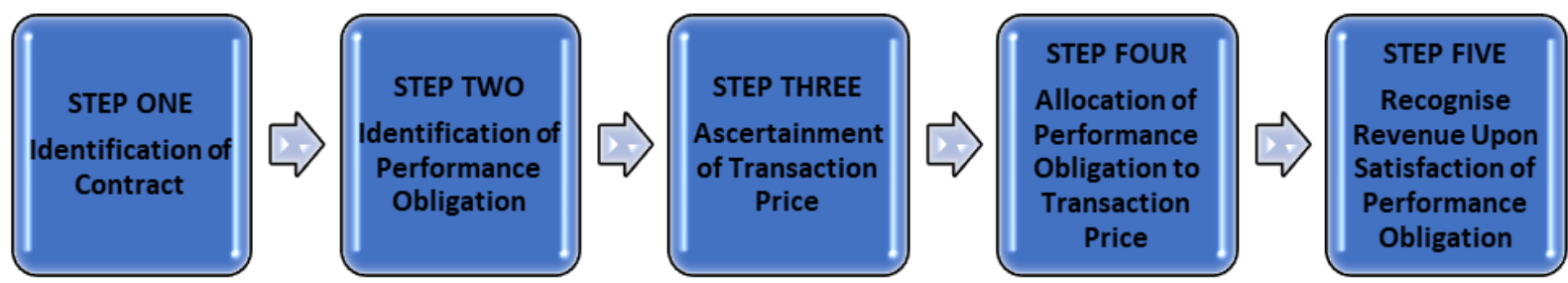

Source: International Accounting Standards Board (IASB) 2014a "IFRS 15: Revenue from Contracts (50)"

Figure 1. The Five-Step Revenue Recognition Model 
Ezeaga [35] investigated the post-adoption effect of IFRS on the corporate performance of listed deposit money banks in Nigeria. Eleven out of twenty-one institutions were purposively selected for the study and data collected was analyzed using percentages, tables and ratios. The study found that IFRS adoption positively impacted the profitability of the surveyed financial institutions. The results of this study are however not in accordance with the works of Ofoegbu and Odoemelam [36] who concentrated on listed non-financial companies in Nigeria. The study utilized a combination of content analysis and multiple regression techniques to analyze data pooled from sixty-four listed entities. Specifically, the study showed that the post-adoption effect of IFRS (increased disclosures) on the corporate performance of the entities was insignificant. The difference in the results may be because deposit money banks are under greater regulatory scrutiny and IFRS adoption and implementation are made more mandatory in the institutions.

Trabelsi [29] evaluated the effect of IFRS 15 early adoption on the corporate performance of quoted property investment companies in Dubai. The research showed that early adoption of IFRS 15 impacted positively on accounting numbers proxied by earnings and shareholders' equity. The listed companies adopted the modified retrospective method in their financial reporting which aided them to fast-track revenue recognition and conversely delay the recognition of qualifying expenses thus amplifying their earnings.

Ferreira [27] studied the impact of IFRS 15 on the corporate performance of the telecommunication industry using thirty (30) quoted Portuguese and Spanish companies as benchmarks. Data extracted from the sampled firms were analyzed using tables, ratios, and percentages. The study revealed that the adoption of IFRS 15 led to increases in EBITDA but also a net decrease in profitability due to increased provisioning for contract costs. It however recommended that the quality of disclosures should be improvedto foster inter-firm comparison.

Stradler and Napier [4] assessed the effect of IFRS 15 first-time adoption on the operational and corporate performance of listed companies in Europe. Data was collected from the annual report of forty-eight (48) quoted companies drawn from nine European countries. The study found that while the standard by the entities led to an increase in levels of disclosures, minimal impact on the accounting numbers was reported. Similarly, IFRS 15 adoption had an insignificant impact on the need to overhaul business operations. The research findings are therefore an encouragement for firms who are still undecided about proceeding with implementation due to perceived likely negative impact on their operations. The views on the impact of IFRS 15 on accounting numbers are however negated by the studies of Aladwan [37] which used Jordanian impacted industries as its benchmark. Specifically, the study found that the stock prices and revenues of the affected industries were positively influenced in terms of accountability and quality of financial reporting.

Levanti [30] focused on examining the effect of IFRS 15 first-time adoption as it relates to the reporting and performance of credit institutions operating in Romania. Data analyzed was obtained from the public records of thirteen banks with a focus on the first year of adopting IFRS 15 principles on their financial statements. The study found that there was no significant impact on IFRS 15 adoption on the financial results of the surveyed firms. The researcher argued that this may be in part due to the poor levels of disclosures and general knowledge deficiencies on the applicability of IFRS 15 principles by the affected institutions.

Sawalqa and Qtish [55] investigated the extent of adoption of some selected financial reporting standards (inclusive of IFRS 15) by Jordanian firms operating in the baking, insurance, industries and services sectors. The researchers focused on eliciting response from preparers and users of accounting records with particular interests in ascertaining the implementation challenges associated with the adoption process. The study found that comparatively, IFRS 15 was one of the moderately adopted financial reporting standard in Jordan. Additionally, pressures from international and local regulatory bodies had a positive impact on the level of adoption of financial reporting standards in the country.

Zulaikha and Juliarto [56] carried out a study which attempted to establish a link between certain institutional environmental factors and the level of IFRS implementation and the quality of accounting numbers in adopting countries. The study suggested that national culture, social and political factors such as the corruption index of adopting countries could significantly influence the level of IFRS implementation and subsequently extent of accounting qualities. They therefore posited that for a balanced perspective beyond quantitative measures, other qualitative measures such as politics and corruption must be considered in assessing the effectiveness or otherwise of IFRS implementation.

\subsection{Theoretical Framework}

This study is anchored in the theory of value relevance. The theory of value relevance in accounting is traceable to the pioneering works of Ball and Brown [38] and Beaver [39]. They anchored the theory as an extension of the efficient market hypothesis. Financial statements represent the most accessible piece of an information repository for external users to validate a company's performance. Qualitative financial statement information is a condition for the proper functioning of the stock market, which is of particular importance to shareholders and investors [40]. 
Proper functioning of the stock market implies one where interferences or manipulations are either minimized or eliminated. When market efficiency is not optimal, shareholders' and investors' decision-making is still impacted by the quality of financial statement information available. This is especially true for developing economies such as Nigeria where complete market efficiency remains a challenge. Olugbenga and Atanda [41] opine that the notion of value relevance emphasizes the correlation that subsists between accounting information variables and the intrinsic value of business entities. It is also a theory that stresses the statistical association between financial information and stock market prices or returns $[42,43]$. Felix and Rebecca [44] however opined that when mixed with conservative practices associated with accounting, value relevance is capable of diminishing stock returns.

This theory of value relevance is particularly germane for this current study as it speaks readily to the extent to which users of financial statements such as shareholders and investors find them to be reliable and relevant for optimal investment decisions. This is especially true given the fact that revenue line items in terms of value usually impact a significant portion of the accounting numbers. Some previous studies have also shown that financial statement information such as earnings has the potentials to influence the equity valuation of firms $[45,46,47]$.

\section{Methodology}

Table 1. Impacted Industries Analysis - Nigeria

\begin{tabular}{|c|c|c|}
\hline & Key Impacted Industry & Listed Company \\
\hline Name & Oil and Gas & Mobil Plc (11 Plc) \\
\hline Mkt Cap & 479.16 & 82.21 \\
\hline$\%$ Mkt Cap & & $17 \%$ \\
\hline & & \\
\hline Name & Telecommunications & MTN Nigeria \\
\hline Mkt Cap & 5080.00 & 3277 \\
\hline$\%$ Mkt Cap & & $65 \%$ \\
\hline & & Dangote Cement Plc \\
\hline Name & Construction & 3655 \\
\hline Mkt Cap & 6455.00 & $57 \%$ \\
\hline$\%$ Mkt Cap & & \\
\hline & & Zenith Bank Plc \\
\hline Name & Banking & 687.58 \\
\hline Mkt Cap & 3080.00 & $22 \%$ \\
\hline$\%$ Mkt Cap & & \\
\hline & & \\
\hline
\end{tabular}

Source: Adapted from Nigerian Stock Exchange (NSE) 2021 Fact Sheet

The study adopted descriptive research design and secondary data were employed in the study. Secondary data used in the study were sourced from the audited financial statements of some selected companies and pronouncements made by professional bodies inclusive of the financial reporting standards, accompanying interpretative statements, exposure drafts of proposed future amendments and from other allied internet sources. The population of the study comprised of key impacted industries in Nigeria was twenty four (24) listed companies while four (4) listed companies representing $82 \%$ of the total market capitalization of the impacted industries was selected as the sample. The data obtained from the listed companies were analyzed using tables, percentages, and charts.

\section{Results and Discussion of Findings}

To achieve the research objective, this study utilized data obtained from the audited annual financial statements of four (4) listed companies, and each comes from the four (4) identified key impacted industries in Nigeria. These four (4) companies were selected based on the fact that each of them contributes at least $17 \%$ of their respective industry size (See Table 1 above) while the ratio of the impacted industries size relative to total market capitalization is $82 \%$.

The annual financial statements for five (5) years from 2016 to 2020 were reviewed and analyzed to capture the impact of Pre-IFRS 15 and Post IFRS 15 adoption on the accounting numbers of the sampled firms. In particular, we observed that all the surveyed firms which are also market leaders in their respective industries elected for early adoption of IFRS 15 in their financial reporting due to regulatory pressures and the increased internationalization of their operations.

\section{Mobil Oil Plc (11 Plc)}

Mobil Oil Plc (now $11 \mathrm{Plc}$ ) is one of the primary listed oil and gas firms in Nigeria. As at April 2021, out of a total market capitalization of N479 billion for the energy sector, the firm accounted for $17 \%$. The company elected early adoption of IFRS 15 in reporting its accounting numbers. Even though it witnessed a change of ownership in mid-2017, this did not impact on financial reporting cycle. Figure 2 showed that the impact of IFRS 15 adjustments to reported revenues and PBT were $0.18 \%$ and $2 \%$ of 2018 implementation year figures respectively, actual growth in revenues and PBT (YOY) were $31.36 \%$ and $15.43 \%$ within the first year of implementation. This suggests that IFRS 15 adoption and implementation had a positive and significant impact on revenues. We note that this is in accordance with the works of Aladwan [37] and Chen et al. [51] who opined that IFRS 15 implementation positively influenced in terms of accountability and quality of financial reporting. 


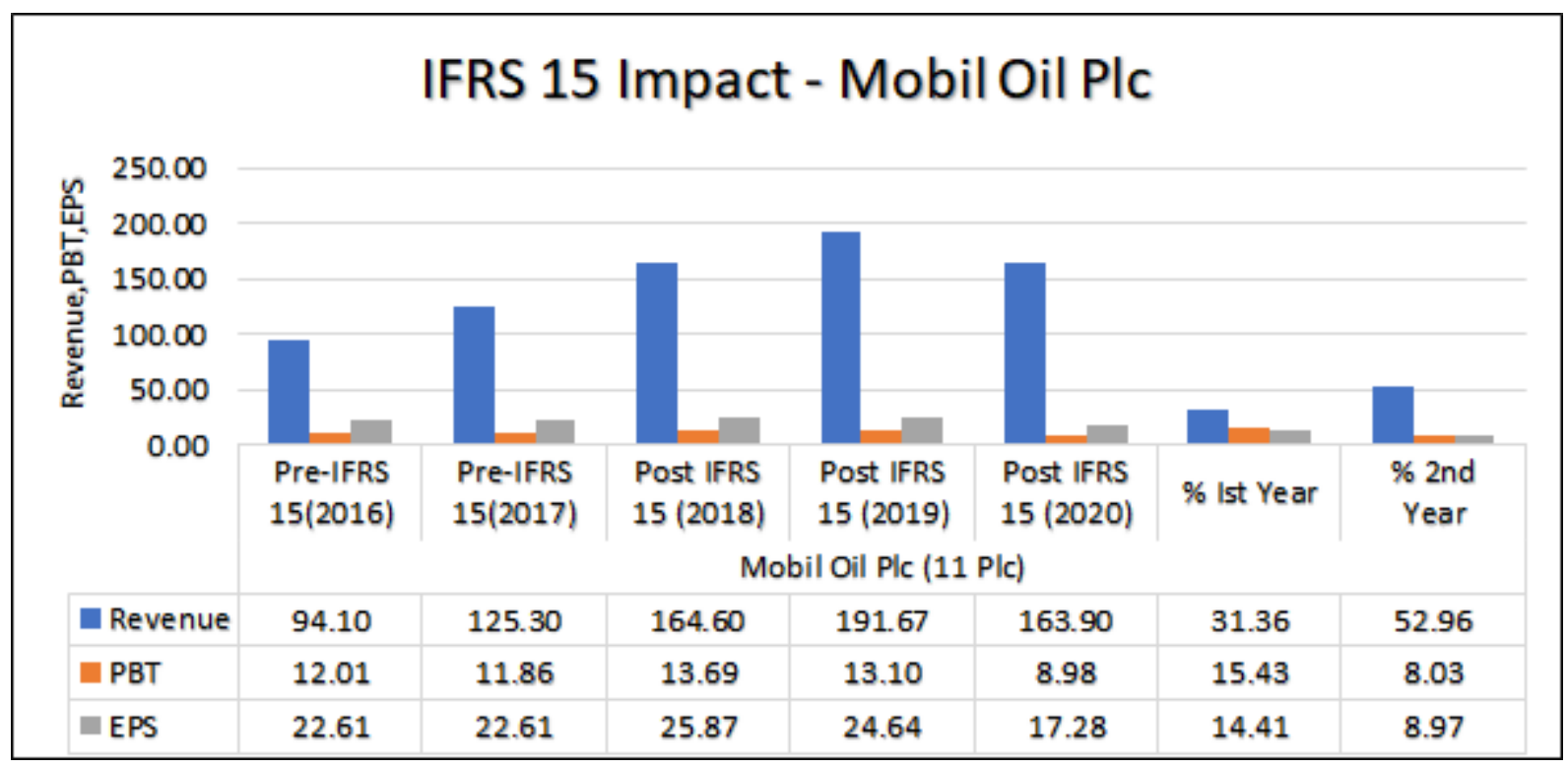

Source: Author's Computation (2021)

Figure 2. Analysis of Pre-IFRS 15 and Post-IFRS 15 Impact (Mobil Oil Plc)

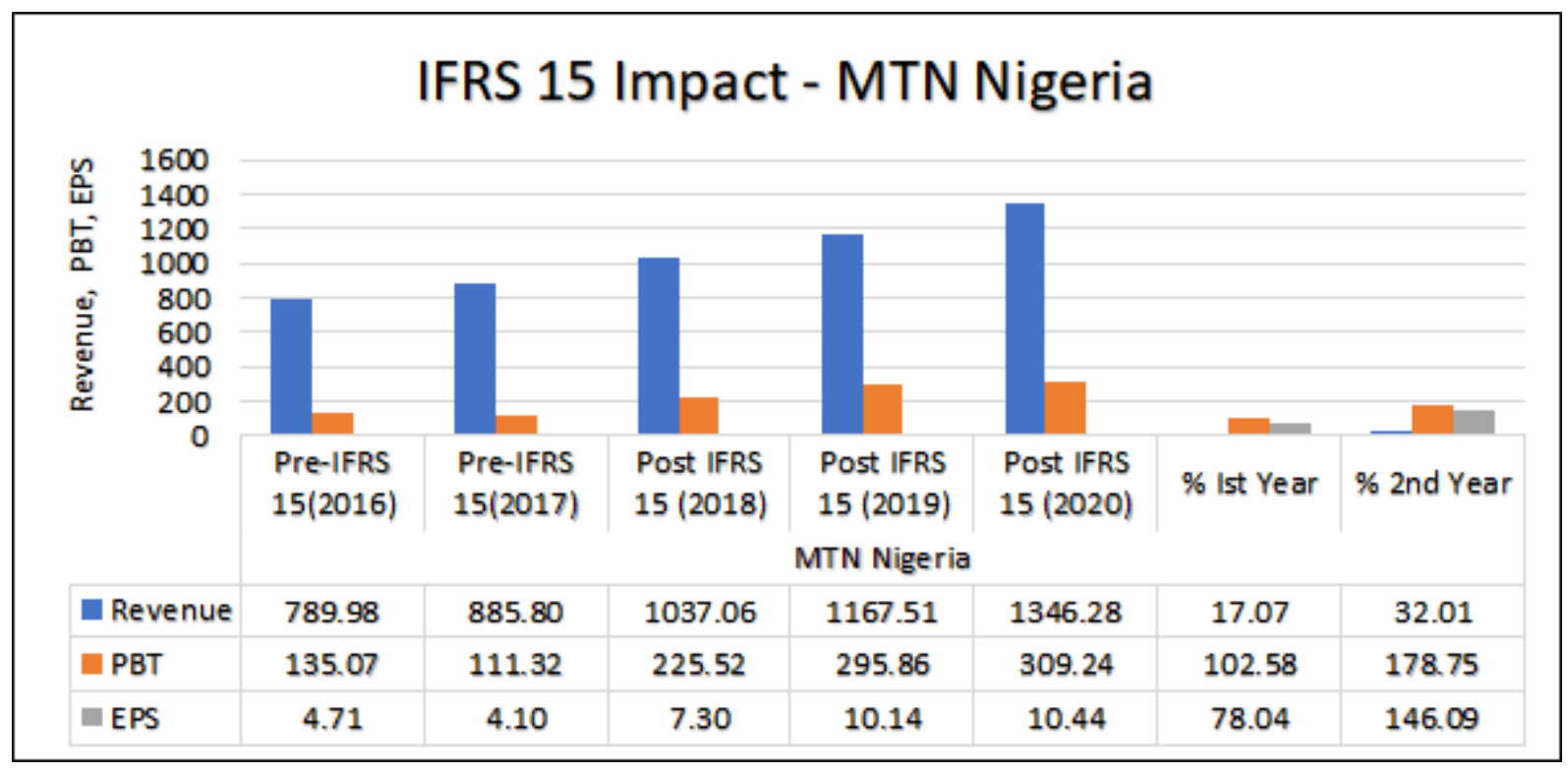

Source: Author's Computation (2021)

Figure 3. Analysis of Pre-IFRS 15 and Post-IFRS 15 Impact (MTN Nigeria)

In terms of qualitative disclosures, we noted that segmental reporting and disaggregation of revenues were not detailed enough. In particular, no practical expedient was disclosed and this is deemed significant because third-party sales contracts constituted $84 \%$ of the reported revenues Pre and Post IFRS 15 adoption in 2017 and 2018 respectively. Furthermore, there were no specific disclosures made on how transaction price was allocated to remaining performance obligations per qualifying contract.

\section{MTN Nigeria}

MTN Nigeria is one of the two (2) listed telecommunications company operating in Nigeria and it accounted for $65 \%$ of the sectoral market capitalization in April 2021. MTN Nigeria adopted the full retrospective approach to revenue recognition and consequently restated its comparative numbers for the 2017 financial year.

We observed that the impact of IFRS 15 adjustments to reported revenues and PBT were $0.39 \%$ and $3 \%$ respectively while the firms' average revenue per user also grew by $1.1 \%$ post-IFRS 15 implementations. However, this pales into insignificance when juxtaposed with the YOY revenue growth rates of $17.07 \%$ and $32.01 \%$ respectively, implying that factors other than IFRS 15 revenue recognition alone accounted for the growth.

Further review showed that the firm accelerated 
revenue recognition in terms of breakages and capitalized contract acquisition costs. The net implication of this, therefore, is that IFRS 15 adoption and implementation had a positive and significant effect on the reported numbers as shown in Figure 3. Also, the practical expedients adopted were properly spelt out thus aiding the reliability and comparability of its reported accounting numbers. These findings are consistent with the studies of Ferreira [27] and Hameed et al [52] which reported that IFRS adoption impacted telecommunications entities in terms of increased contract acquisition costs.

\section{Dangote Cement Plc}

Dangote Cement Plc accounts for 57\% of the total market capitalization of Nigeria's construction sector as at April 2021. It adopted IFRS 15 mainly to allocate consideration between a lease and non-lease components of qualifying contracts. It was observed in Figure 4 that while disclosures relating to revenue disaggregation and segmental revenue recognition were fairly detailed, no practical precedent used to generate the accounting numbers was disclosed thus raising questions as to the reliability of some judgment calls made by the management. A review of the company's Pre and Post IFRS 15 status showed that the company did not make any adjustment for the impact of IFRS 15 notwithstanding the YOY growth rate of $11.87 \%$ after the first year of implementation. This suggested that in the company's opinion, a recheck of its long-term contracts and associated variable considerations did not significantly affect its financial position and performance. This position is corroborated by the works of Boujelben and Kobbi-Fakhfakh [48], Standler and Nadier [4] who found that while adopting the standard by entities led to an increase in levels of disclosures, minimal impact on the accounting numbers was reported. However, this view is not consistent with the studies of Trabelsi [29] and Aladwan [37] who posit that IFRS 15 post-implementation reviews of construction and related industries have a positive and significant effect on financial reporting quality and corporate performance.

\section{Zenith Bank Plc}

Zenith Bank Plc accounted for nearly one quarter (22\%) of the market capitalization of Nigeria's financial landscape as at April 2021. It was observed in figure 5 that Zenith Bank Plc adopted IFRS 15 principles mainly for revenue recognition on its financial guarantee contracts and residual elements of financial instrument contracts that are outside the scope of IFRS 9. Other than the above, IFRS 15 adoption and implementation did have an impact on the entity's accounting numbers. This is exemplified by the review of the company's Pre and Post IFRS 15 status which showed YOY increases in revenues by $4.29 \%$ and $4.57 \%$, while there were also positive and consistent growths in PBT and EPS post-IFRS 15 implementations (from 2018 to 2020). In terms of qualitative disclosures, the entity fairly disclosed the various revenue lines as required by the standard. This finding is supported by the studies of Levanti [30] which revealed that by their nature, financial institutions are more impacted by the provisions of IFRS 9 than IFRS 15. Nonetheless, Levanti [30] argues that an in-depth review of loan agreement contracts of financial institutions may reveal a much more significant IFRS 15 revenue recognition impact.

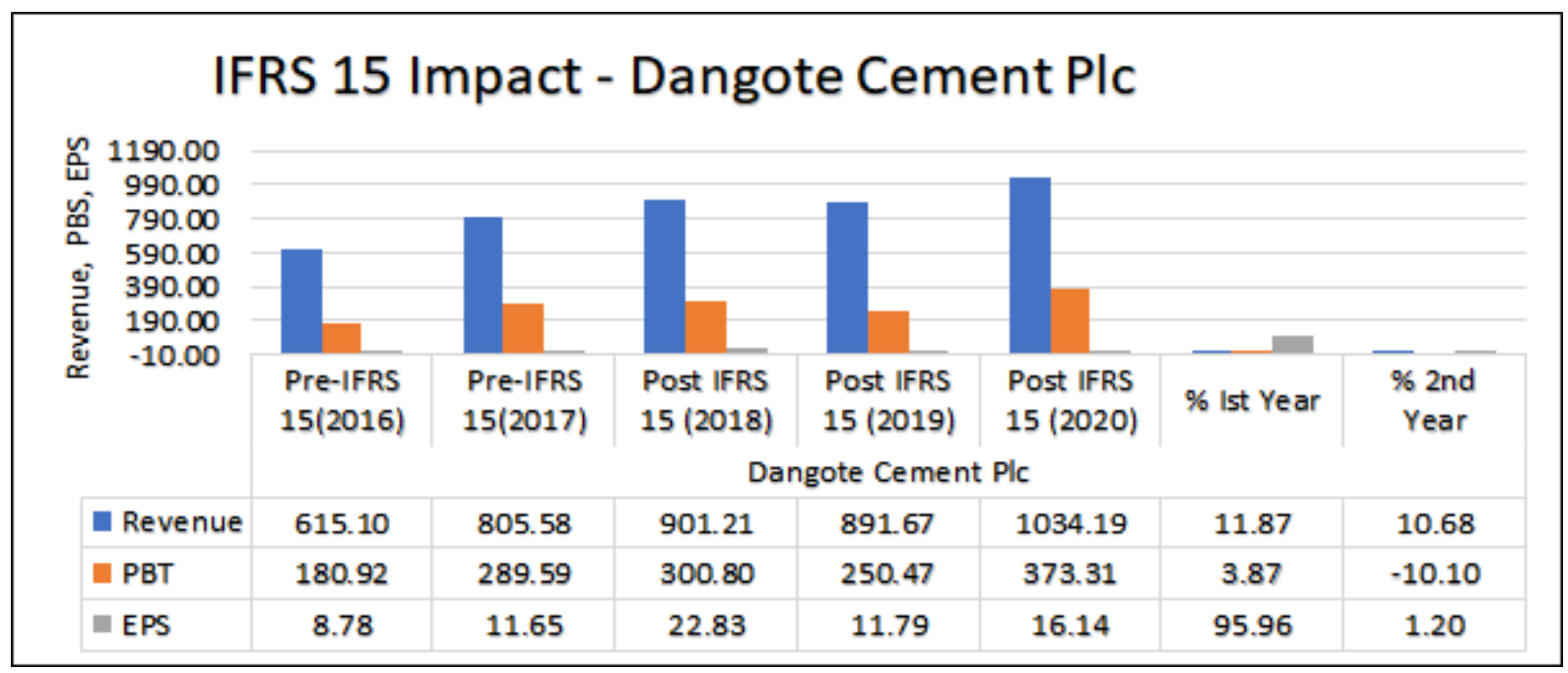

Source: Author's Computation (2021)

Figure 4. Analysis of Pre-IFRS 15 and Post-IFRS 15 Impact (Dangote Cement Plc) 


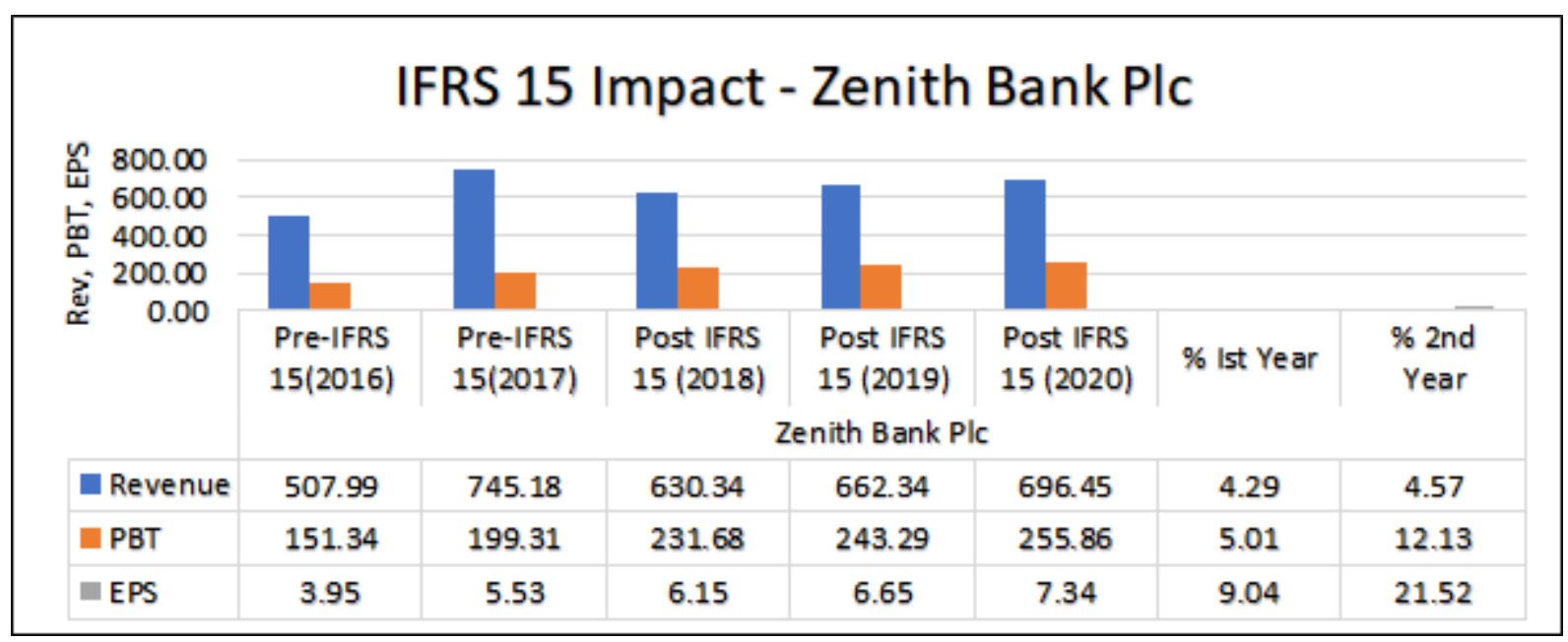

Source: Author's Computation (2021)

Figure 5. Analysis of Pre-IFRS 15 and Post-IFRS 15 Impact (Zenith Bank Plc)

\subsection{Challenges of IFRS 15 Implementation - The Nigerian Perspective}

In Nigeria, IFRS 15 implementation has gathered steam due to the combination of regulatory pressure and the desire to attract foreign portfolio investments to the key sectors of the economy. These sectors include oil and gas, telecommunications, construction, and banking which collectively accounts for over $82 \%$ of the total market capitalization in April 2021 (NSE Factbook 2021). This is depicted below:

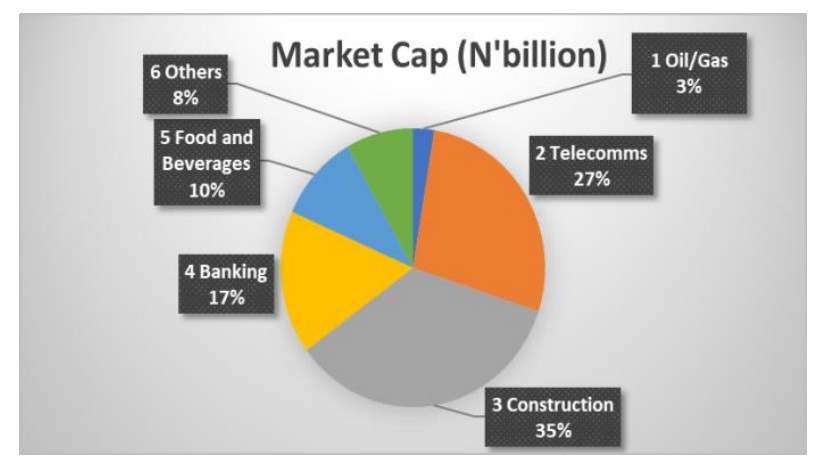

Source: NSE 2021 Fact Sheet (Adapted)

Figure 6. Nigeria Market Capitalization

The implementation of IFRS 15 in these identified key industries has experienced mixed results and challenges. While most listed entities in the impacted industries confirmed early adoption of the standard with effect from the implementation date (January 2018), the level of disclosures has differed based on the level of understanding of the respective company Board of Directors and the extent of judgment calls decided upon.

In the oil and gas industry, the key challenges have revolved around the proper identification and treatment of royalties, income taxes, and level of under-lifts because of the government's inconsistent approach to accounting for receipts [PWC 49]. In this case, revenue recognition and measurement dilemmas arise when the government accepts tax oil instead of cash payments from the oil majors thus leading to the exclusion of the same in their accounting numbers. This has the impact of under-reporting revenues and consequently depleting reported accounting profit. Similarly, in the banking industry, IFRS 15 appears to be only applied for residual elements of contract items which in the estimation of the business entity falls outside the scope of IFRS 9. Challenges arising from the proper delineation of revenues from contractual fees, differences in nature, and product mix have consequently heightened the recourse to the use of subjective judgment calls. For the telecommunication and construction industries, the key challenges related to the need for persistent contract modifications, capitalization of contract costs, and collectability issues. Furthermore, while attempts have been made by the listed companies in each key impacted industry (Table 1) to quantify the extent of the impact of adopting IFRS 15 on their revenue recognition post-implementation, the basis for some of the significant judgment calls made have not been very clear, thus inhibiting full understanding of relevant stakeholders.

\section{Conclusion and Recommendations}

This study set out with the primary objective of exploring the revenue recognition dilemma from the perspectives of the industries most impacted by the adoption of IFRS 15 in Nigeria. The paper identified problem definitions, collectability issues, proper capitalization of costs, and inadequate qualitative disclosures as some of the key post-IFRS 15 implementation challenges confronting listed companies in Nigeria. Analysis of data extracted from the sampled firms showed that IFRS 15 post-implementation had a positive and significant effect on accounting numbers 
proxied by revenues, profit before tax, and earnings per share respectively. The study also found that listed firms are aligned with the need to adopt and fully implement IFRS 15 in their financial reporting in response to regulatory pressure and increased internationalization of operations. The study, therefore, concluded that the adoption and implementation of IFRS 15 had a positive and significant effect on accounting numbers of listed firms in Nigeria.

The study recommended that the Board and Management of companies operating in the IFRS 15 impacted industries should always provide greater clarity on the basis used for arriving at the significant judgment calls they make. This will foster reliability and comparability of the financial statements. Also, the Financial Reporting Council, external auditors, and other assessors need to develop workable methodologies to monitor and tighten compliance with both quantitative and qualitative IFRS 15 disclosure requirements.

\section{REFERENCES}

[1] Zhang, Y. "Revenue recognition timing and attributes of reported revenue: The case of software industry's adoption of SOP 91-1." Journal of Accounting and Economics. Vol. 39 no 3, pp. 535-561, 2005.

[2] Stubben S.R. "Discretionary revenues as a measure of earnings management." The Accounting Review. Vol. 85 no 2, pp. 695-717, 2010.

[3] Jones, J. P., \& Pagach, D. "The next step for revenue recognition." The CPA Journal. Vol. 83 no 10, pp. 30-34, 2013.

[4] Napier C.J., \&Stadler. "The real effects of a new accounting standard: the case of IFRS 15 Revenue from Contracts with Customers."Accounting and Business Research Journal. Vol. 50 no 5, pp. 474-503, 2020.

[5] Vinnari EM, Näsi S. "Creative accrual accounting in the public sector: milking "water utilities to balance municipal budgets and accounts." Financial Accountability and Management. Vol. 24 no 2, pp. 97-116, 2008.

[6] Tutino M, Pompili M. "Fair Value Accounting and Management Opportunism on Earnings Management in Banking Sector: First Evidences." Corporate Ownership and Control Journal. 15(2), Vol. 15 no 2, pp. 59-69, 2017.

[7] Daske H, Hail L, Leuz C, Verdi R. "Adopting a label: Heterogeneity in the economic consequences around IAS/IFRS adoptions." Journal of Accounting Research. Vol. 51 no 3, pp. 495-547, 2013.

[8] Capkun V, Collins D, Jeanjean T. "The effect of IAS/IFRS adoption on earnings management (smoothing): A closer look at competing explanations." Journal of Accounting and Public Policy. Vol. 35 no 4, pp. 352-394, 2016.

[9] Ugrin JC, Mason TW, Emley A. "Culture's consequence: The relationship between income-increasing earnings management and IAS/IFRS adoption across cultures." Advances in Accounting Journal.Vol. 3 no 7, pp. 140-151, 2017.

[10] Haggenmüller, S. "Revenue recognition under IFRS 15: A Critical Evaluation of predefined purposes and implications for improvement." Doctor of Business Administration (DBA) Thesis. University of Gloucestershire, 2019.

[11] Kivioja T. The Impact of IFRS 15 on Analyst Forecast Accuracy. University of Oulu. Masters' Thesis, 2018.

[12] Warnlund A, Klein T. "IFRS 15: A critical evaluation of the newly issued revenue recognition standard's ability to reflect economic reality." Masters' Thesis, 2020.

[13] Peters M. The new IFRS 15 standard: implementation challenges for Belgian companies. University of Liege. Masters' Thesis, 2016.

[14] Grosu V., \& Socoliuc M. "Effects And Implications Of The Implementation Of Ifrs 15 - Revenue From Contracts With Customers." Management Strategies Journal, Constantin Brancoveanu University. Vol. 4 no 4, pp. 95-106, 2016.

[15] OnciouI., \& Tanase A.E. "Revenue from Contracts with Customers under IFRS 15: New Perspectives on Practice." Euroeconomica Journal. Vol. 35 no 2, pp. 1-10, 2016.

[16] Tanko M. "The Effect of International Financial Reporting Standards (IFRS) Adoption on the Performance of Firms in Nigeria." International Financial Reporting Standards (IFRS) Conference, Lagos, May 1-2, 2012.

[17] Odoemelam N., Okafor R.G., Ofoegbu N.G. "Effect of international financial reporting standard (IFRS) adoption on earnings value relevance of quoted Nigerian firms." Cogent Business \& Management Journal. Vol. 6 no 1, pp. $164-175,2019$

[18] Costa Lourenco, I. M. E. \& Mota de Almeida Delgado Castelo Branco, M. E. "Main consequences of IFRS adoption: Analysis of existing literature and suggestions for further research." Revista Contabilidade \& Financas. Vol. 26 no 68, pp. 126-139, 2015.

[19] Armstrong, C.S., Barth, M.E., Jagolinzer, A.D. \& Riedl, E.J. "Market Reaction to the Adoption of IFRS in Europe", The Accounting Review.Vol. 4 no 5, pp. 34-39, 2010.

[20] Sun, J., Cahan, S.F. \& Emanuel, D. "How Would the Mandatory Adoption of IFRS Affect the Earnings' quality of U.S. Firms? Evidence from Cross-Listed Firms in the U.S.", Accounting Horizons, 25(4), Vol. 25 no 4, pp. 837-860, 2011

[21] Zicke J., Kiy F. "The effects of accounting standards on the financial reporting properties of private firms: evidence from the German Accounting Law Modernization Act." German Academic Association for Business Research Journal, Vol. 10 no 2, pp 215-248, 2017.

[22] Aboud, A., Roberts, C. \& Zalata, A. M. "The impact of IFRS 8 on financial analysts' earnings forecast errors: EU evidence." Journal of International Accounting, Auditing and Taxation. Vol. 33 no. 12, pp. 2-17, 2018.

[23] Aurora, C., Bontas, B. "New Approaches on Revenue Recognition and Measurement." Management Strategies Journal. Vol. 8 no 1, pp. 375-382, 2014. 
[24] Oyedokun, G. "Revenue Recognition Paradox: A Review of IAS 18 and IFRS 15". SSRN Electronic Journal. Vol. 3 no 1, pp. 1-26, 2016.

[25] Khamis. A.M. "Perception of Preparers and Auditors on New Revenue Recognition Standard (IFRS 15): Evidence from Egypt." Journal Dinamika Akuntansi Dan Bisnis, Vol. 3 no 2, pp. 11-18, 2016.

[26] Ciesielski, J. T. \&Weirich, T. R. "Revenue recognition: How it will impact three key sectors." Journal of Corporate Accounting \& Finance. Vol. 26 no 3, pp. 31-39, 2015.

[27] Ferriera A.F. "The Impact of Ifrs 15 On The Telecommunications Sector -The Case Of Portuguese And Spanish Listed Companies." University of Porto. Masters Thesis, 2020.

[28] Tysiac, K. "Revenue Recognition: No Time to Wait." Journal of Accountancy. Vol. 218 no 1, pp. 40-43, 2014.

[29] Trabelsi, N. S. "IFRS 15 early adoption and accounting information: The case of real estate companies in Dubai." Academy of Accounting \& Financial Studies Journal. Vol. 22 no 1, pp. 1-12, 2018.

[30] Levanti D. “Applicability of IFRS 15 Principles For The Banking Industry: An Analysis With Reference To The Credit Institutions In Romania." Ecoforum Journal. Vol. 2 no 22, pp. 1-9, 2020.

[31] Tutino, M., Regoliosi, C., Mattei, G., Paoloni, N. \& Pompili, M. "Does the IFRS 15 impact earnings management? Initial evidence from Italian listed companies." African Journal of Business Management. Vol. 13 no 7, pp. 226-238, 2019.

[32] KPMG. IFRS 15 Revenue. It's time to engage. High level impact assessment for Management, 2016.

[33] Forshay, T. Exploring Revenue Recognition in the Local Community. State University of New York. Masters Thesis, 2017.

[34] Dalwai T, Chugh G, Dinesh S, \&Mohammadi S. "Oman's Response To The New Accounting Standard: Ifrs 15 Revenue From Contracts With Customers.” International Conference on Implications of IFRS for Corporate Reporting. March, 2015.

[35] Ezeaga C.M. "Impact of International Financial Reporting Standard (IFRS) Adoption on Financial Reporting Practice of Selected Commercial Banks in Nigeria." Journal of Policy and Development Studies. Vol. 11 no 2, pp. 21-43, 2015.

[36] OdoemelamN., \& Ofoegbu N.G. "International financial reporting standards (IFRS) disclosure and performance of Nigeria listed companies." Cogent Business \& Management Journal. Vol. 5 no 1, pp. 154-167, 2018.

[37] Aladwan, M. "Fluctuations of Stock Price and Revenue after the Early Adoption of IFRS 15, Revenue from Contracts with Customers." Italian Journal of Pure and Applied Mathematics, 4(1), Vol. 4 no 1, pp. 691-707, 2019.

[38] Ball, R. \& P. Brown. "An Empirical Evaluation of Accounting Income Numbers." Journal of Accounting Research. Vol. 6 no 1, pp159-178, 1968.

[39] Beaver, W. H. "The information content of annual earnings announcements." Journal of Accounting Research, Vol. 6 no 1, pp 67-92, 1968.

[40] Davies D.S., \& Macfubara M.S. "Financial Risk and Value Relevance of Accounting Information: Evidence from Nigeria Quoted Insurance Firms." Journal of Accounting and Financial Management. Vol. 4 no 3, pp. 45-64, 2018.

[41] Olugbenga, A.A., \& Atanda, O.A. "Value relevance of financial accounting information of quoted companies in Nigeria: a trend analysis." Research Journal of Finance and Accounting, 5(8), Vol. 5 no 8, pp. 86 -95, 2014.

[42] Francis, J. \& Schipper, K. "Have financial statements lost their relevance?" Journal of Accounting Research Supplement. Vol. 37 no 12, pp. 319-352, 1999.

[43] Umoren A.O, Akpan P.W, and Ekeria E.V. "Value Relevance of Accounting Information in Nigerian Listed Financial Companies." Advances in Research Journal. Vol. 16 no 1 , pp 1-8, 2018.

[44] Felix U.O., Rebecca U.I. "Theory of Conservatism and Value Relevance of Accounting Information." Journal of Accounting \& Marketing. Vol. 4 no 1, pp. 1-8, 2015.

[45] Ivica Pervan \& Marijana Bartulović. "Value relevance of accounting information: evidence from South Eastern European countries." Economic Research Journal. Vol. 27 no 1, pp. 181-190, 2014.

[46] Barth, M.E., Landsman, W.R. \& Lang, M.H. "International Accounting Standards and Accounting Quality", Journal of Accounting Research, 46, Vol. 4 no 6, pp. 467-498, 2008.

[47] King, R. D., \& Langli, J. C. "Accounting diversity and firm valuation." The International Journal of Accounting, Vol. 33, pp 529-567, 1998.

[48] Boujelben S., Kobbi-Fakhfakh S. "Compliance with IFRS 15 mandatory disclosures: an exploratory study in telecom and construction sectors." Journal of Financial Reporting and Accounting. Vol. 18 no 4, pp. 707-728, 2020.

[49] PWC. A walk in the park: IFRS 15 implementation efforts of 2018 interim reporters in the oil and gas industry, 2018

[50] International Accounting Standards Board. IFRS 15 revenue from contracts with customers, in IASB (ed.), International Financial Reporting Standards: A guide through IFRS official pronouncements, issued at 01 July 2014 with extensive cross-references and other annotations, Part A1, The IFRS Foundation, London, pp. A683-A743, 2014a.

[51] Chen, H., Tang, Q., Jiang Y. \& Lin, Z. "The Role of International Financial Reporting Standards in Accounting Quality: Evidence from the European Union", Journal of International Financial Management and Accounting.Vol. 21 no 3, pp. 56- 61, 2010.

[52] Hameed A.M., Al-taie B. F., \& Bushra Najem A.M. "The Impact of IFRS 15 on Earnings Quality in businesses such as hotels: critical evidence from the Iraqi environment." African Journal of Hospitality, Tourism and Leisure. Vol. 8 no 4, pp. 1-11, 2019.

[53] Peters M., (2016). The new IFRS 15 standard: implementation challenges for Belgian companies. University of Liege. Masters' Thesis.

[54] Phang, S. Y., \& Mahzan, N. (2017). The responses of 
Perspectives from Key Impacted Firms in Nigeria

Malaysian public listed companies to the IFRS convergence. Asian Journal of Business and Accounting, 6(1), 95-106.

[55] Fawzi A. Al Sawalqa, Atala Qtish (2021). IAS/IFRS in Jordan: Adoption, Implementation and Determinants. Universal Journal of Accounting and Finance, 9(2), 232-244. DOI: 10.13189/ujaf.2021.090213.
[56] Fuad, Zulaikha, Agung Juliarto (2021). Linking Institutional Environment to the IFRS and Accounting Quality: A Proposed Framework. Universal Journal of Accounting and Finance, 9(3), 347-351. DOI: 10.13189/ujaf.2021.090308. 